\title{
Book Review: The Art of Fermentation An in-depth exploration of essential concepts and processes from around the world
}

\author{
by Sandor Ellix Katz, Foreword by Michael Pollan. 2012. Chelsea \\ Green Publishing. White River Junction, Vermont, USA. 498 pp. ISBN \\ 978-1-60358-286-5 (hardcover), ISBN 978-1-60358-364-0 (ebook) ${ }^{1}$
}

Jill Martineau Cornish ${ }^{2}$ and Eric Spagnuolo ${ }^{3}$

"Fermentation is the transformation of food by various bacteria, fungi, and the enzymes they produce." (p. 1). More broadly, fermentation refers to the chemical reactions that alter chemicals used as sources of energy in the absence of oxygen. Although biology textbooks typically use alcohol fermentation and lactic acid fermentation as paradigms of the phenomena, actually these series of chemical reactions are known from dozens of chemically different processes. For instance, the professor from whom we took a course in Fermentation told us that once a former student and his partner gave him a bottle of wine named Wine by "common name of a man". A few weeks later, our professor needed to carefully re-label the remnants in the bottle Vinegar by "common name of a man".

Why is fermentation important? According to Katz, "as much as one-third of all food eaten by human beings worldwide is fermented" (p. 1). That, in and of itself, is reason enough for us to study the process. Why, then, is it that we in North America generally are not familiar with this process, when it "has played [such an] instrumental role in human cultural evolution" (p.1)?

In gathering the information for his second book on fermentation - an earlier volume, published in 2003, Wild Fermentation: The Flavor, Nutrition, and Craft of Live-Culture Foods, is still available - Katz traveled widely to experience what Michael Pollan calls in his Foreword of the book "the transformative power of fermentation" in far-flung cultures. Yet, clearly, it is not likely that everyone will share Katz's enjoyment of all the fermented foods.

Along with descriptions and practical "recipes," Katz provides a compendium of historical facts and figures. Much of the material is written in layman's terms, specifically to encourage individuals to try to make and consume fermented food-stuffs. Although we already eat some fermented foods

\footnotetext{
${ }^{1}$ Submitted on August 25, 2013. Accepted on August 27, 2013. As it is the policy of this editor, this Book Review was sent to the author, who is gratefully acknowledged, for his comments.

${ }^{2}$ Rockville, Maryland, USA. E-mail: jillatc2@gmail.com.

${ }^{3}$ Louisville, Kentucky, USA. E-mail: ericspag@ gmail.com.
} 
- notably yogurt, cheese and beer - North Americans may find many of Katz's less familiar examples, such as Darfur's kawal, Finnish viili, Japanese amazake, and Mexican atole agrio, peculiar and off-putting. With continued reading, you will find the author's enthusiasm opens the door to experimentation of new culinary adventures.

Interested "foodies" will find Katz's instructions easy to follow and his descriptions of worldwide consumption interesting. Many readers will not be able to resist making their first fermented product - e.g., a sourdough yeast or sauerkraut - before completing the book. (Another book, expected out this fall from Mary Karlin, includes many more recipes: Mastering Fermentation: Recipes for Making and Cooking with Fermented Foods.) However, scientists, and those who want the more detailed hard science of the fermentation process, might be disappointed in the lack of sidebars for detailed explanations of the chemical nuances. For those, students may prefer the Institute of Food Technologists' far more in-depth 2006 textbook by Robert W. Hutkins, Microbiology and Technology of Fermented Foods.

Katz points out that, throughout history, fermentation has been an important means of natural food preservation for both man and beast. Even today, in many parts of the world, such as Nepal, Bhutan, China and broad underdeveloped areas in Africa, fermentation provides a means of keeping food without refrigeration or other processing and is a way to introduce bacteria, fungi and enzymes into the menu.

As Katz points out in his concluding chapters, fermentation is also involved in many important agricultural, medical, energy and waste-processing operations. Compost is an important means of breaking down of plant waste for further use; silage (animal feed) is fermented grains stored for winter use; human waste is processed as sewage to dispose of harmful materials. Katz makes it clear: fermentation is a fundamental, practical part of every culture worldwide. His New York Times bestseller, The Art of Fermentation, has something for everyone who has an interest in the topic.

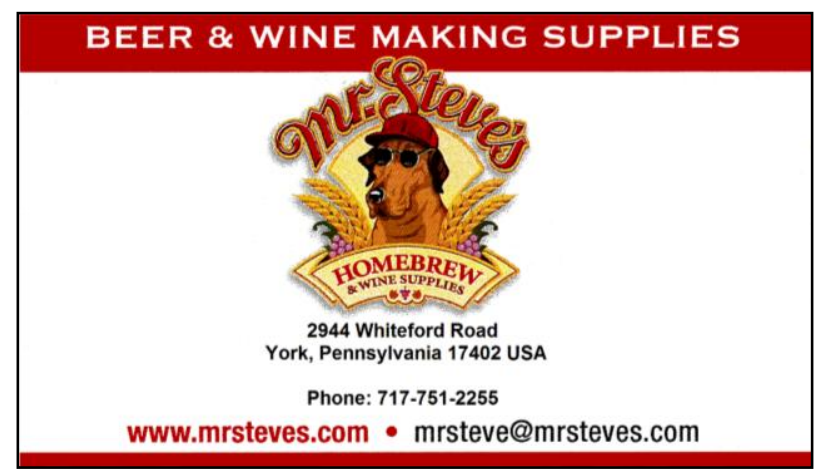

